\title{
The Biological and Economical Feasibility of Feeding Barley Green Fodder to Lactating Awassi Ewes
}

\author{
Abd Rahim M. A. Saidi ${ }^{1}$, Jamal Abo Omar ${ }^{2 *}$ \\ ${ }^{1}$ Al Barakah Sheep Farm, Tulkarm, Palestine \\ ${ }^{2}$ An-Najah National University, Nablus, Palestine \\ Email:
}

Received 28 February 2015; accepted 26 March 2015; published 31 March 2015

Copyright (C) 2015 by authors and Scientific Research Publishing Inc.

This work is licensed under the Creative Commons Attribution International License (CC BY). http://creativecommons.org/licenses/by/4.0/

(c) (i) Open Access

\begin{abstract}
The objective of this research was to investigate the biological and economical values of hydroponic barley (HB) on lactating Awassi ewes. A total of 48 lactating ewes were used in a feeding trial in two groups. The first was fed a regular lactation TMR ration while ewes in the second treatment were fed similar ration except that regular wheat hay was totally replaced by HB for 120 days feeding trial. Results of the experiment showed that the green fodder yield in 8 days germination cycle was $7.5 \mathrm{~kg}$ per $1 \mathrm{~kg}$ barley grains of green fodder. HB had no effects on feed intake (FI), body weight changes, milk yield, and milk composition; however, HB had positive effects on ewe's health conditions, mortalities, conception rates and abortion. In conclusion, HB can be used as feed for lactating sheep as cost of feed can be reduced by $42 \%$.
\end{abstract}

Keywords

Hydroponic Barley, Awassi Ewes, Performance

\section{Introduction}

The technology of green fodder production is especially important in the regions like Palestine where forage production is limited [1]. The green fodder is produced from grains, having a high germination rate and grown for a short period of time in a special chamber that provides the appropriate growing conditions [2]. The adoption of this technique has enabled production of fresh forage from oats, barley, wheat and other grains [3].

Over recent years, severe shortages in food supplies for livestock have been experienced in Palestine as well

"Corresponding author.

How to cite this paper: Saidi, A.R.M.A. and Abo Omar, J. (2015) The Biological and Economical Feasibility of Feeding Barley Green Fodder to Lactating Awassi Ewes. Open Journal of Animal Sciences, 5, 99-105.

http://dx.doi.org/10.4236/ojas.2015.52012 
as many other countries in the region, mainly, due to repeated droughts as well as shortages of water for irrigation [1] [4]. Many projects to produce forages have been established during the last two decades to cover some green and dry forage needs in these countries [4]. However, scarcity of adequate fresh water supplies may pose challenges for sustainability of the field projects especially with utilizing ground water for irrigation, which is consumed in large amounts as these countries are characterized with very high rates of evapotranspiration and soils of low capacity to retain water.

It is well documented that feed costs make more than $75 \%$ of total production costs of sheep projects [1].

The majority of sheep raised locally are of the Awassi breed [5]. It is a fat-tailed breed. Under the extensive and semi intensive sheep production system that is adopted by farmers' at large scale, feeding sheep in the off season results in great expenses on concentrated and roughage feeds.

This study was undertaken to determine and assess the biological and economical characteristics of $\mathrm{HB}$ and its effects on the performance of lactating Awassi ewes under Palestinian conditions.

\section{Materials and Methods}

The study was composed of two parts, first was to construct a hydroponic system for the assessment of HB biologically and economically, the second is feeding trial using lactating Awassi ewes.

\subsection{The Hydroponic System}

The production of $\mathrm{HB}$ was conducted under temperature controlled conditions $\left(22^{\circ} \mathrm{C} \pm 1^{\circ} \mathrm{C}\right)$ and natural illumination at growth chamber at the project site, Tulkarm city, Palestine.

The hydroponic system is composed of a hydroponic chamber with an area of $33 \mathrm{~m}^{2}$. The chamber is composed of metal frame and shelves. Shelves in the chamber hold 126 trays with capacity of chamber to produce approximately one ton of green fodder per growth cycle ( 8 days). Plastic trays with dimensions $90 \times 30 \times 4 \mathrm{~cm}$ were used for growing barley grains. These trays were obtained from the local market of Nablus city, Palestine. An air conditioning was used to control temperature inside the growth chamber which was maintained at $22^{\circ} \mathrm{C} \pm$ $1^{\circ} \mathrm{C}$. The relative humidity in the growth room was $65 \%$.

\subsection{Plant Material}

Barley (Hordeumvulgare) grains were obtained from the local market of Tulkarm city, Palestine. Seeds were subjected to a germination test to check for their viability before being used; the result of the germination test was $80 \%$.

\subsection{Treatment of Seeds before Planting}

Seeds were cleaned from debris and other foreign materials. Then the cleaned seeds were sterilized by soaking for 30 minutes in a $20 \%$ sodium hypochlorite solution to control the formation of mould. Planting trays were also cleaned and disinfected. The seeds were then washed well from residues of bleach and resoaked in tap water overnight (about 12 hours) before planting.

\subsection{Seed Planting and Irrigation}

Seeds of were sown in the planting trays which have holes at the bottom to allow drainage of excess water from irrigation. The seeding rates used in this experiment were about $1000 \mathrm{~g}$ of barley grain per tray. Trays were irrigated manually with tap water twice a day (early in the morning and late in the afternoon) at a fixed rate of 500 $\mathrm{ml} /$ tray/day. Drained water out of irrigation was collected in plastic containers which were placed under each planting tray and measured.

\subsection{Fodder Yield}

After 8 days from seeding, the fodder total fresh and dry fodder yields were recorded and ratio of produced green fodder: initial planted seeds weight was calculated. A representative fresh plant samples (about 200 grams) from every tray were taken at harvest, oven-dried at $70^{\circ} \mathrm{C}$ for 48 hours, and weighed to compute the moisture content. Fodder samples were collected from d-3 to d-8 of germination for later chemical analysis. Costs of in- 
puts (barley grain, water, electricity, labor) were recorded then cost of kg HB was calculated.

\subsection{Performance Trial}

The feeding trial was conducted at a sheep farm at Tulkarm, Palestine where 48 lactating Awassi ewes were used. Ewes were randomly chosen from the sheep flock at a private sheep farm. Ewes were in second and third lactation seasons at start of the experiment. Ewes were separated and fed individually throughout the feeding trial. The green barley fodder was fed as part of total mixed ration (TMR) (Table 1).

Ewes were randomly divided into two experimental groups with 24 ewes in each group and 6 replicates for each experimental group in a complete randomized design. Group 1 served as control group and fed a regular lactation diet. Ewes in group 2 were fed a total mixed ration where (HB) was incorporated instead of wheat hay (Table 1). Rations fed to ewes in control group were formulated to meet the recommended requirements by the NRC [6] while rations in the second were than the NRC recommendation.

Daily feed intake was recorded along with feed refusal. Feed and refusal samples were taken for later analysis. Ewes' body weight was monitored on biweekly basis. Milk production was measured daily. Milk samples were collected weekly for milk quality assessment. The duration of the performance trial was 120 days.

\subsection{Chemical Analysis}

Hydroponic samples as well as ration samples (intake and refusal) were analyzed for the proximate analysis fractions (DM, CP, ash, ether extract and crude fiber) as well as for ADF and NDF fractions using AOAC [7] procedures.

Milk was analyzed for DM, total protein, casein and fat using Gelbert procedure.

\subsection{Statistical Analysis}

Analysis of variance was performed using the Statistical Analysis System (SAS) [8]. Differences among the means were determined by the Duncan's multiple range test with a significance defined at $\mathrm{P}<0.05$.

\begin{tabular}{ccc}
$\begin{array}{l}\text { Table 1. Ingredients and chemical composition of rations fed } \\
\text { to Awassi ewes. }\end{array}$ & HB \\
\hline Diets ingredient composition & Control & 40 \\
\hline HB & 0 & 45 \\
Concentrate (18\% CP) & 45 & 15 \\
Wheat bran & 30 & 0 \\
Wheat straw & 25 & \\
Chemical composition & & 36 \\
Dry matter & 90 & 12.0 \\
Crude protein & 14.0 & 14.4 \\
Crude fiber & 13 & 35.4 \\
NDF & 34 & 11.9 \\
ADF & 29 & 4.5 \\
Ash & 6 & 2.2 \\
Calcium & 1.5 & 1.1 \\
Phosphorus & 0.6 & 1064 \\
Cost/ton (NIS) & 1510 &
\end{tabular}




\section{Results and Discussion}

\subsection{Biomass of HB}

Results of this study showed that the green fodder with lush vegetation can be produced in 8 days from planting to harvest using hydroponic technique. The net green product was $7.5 \mathrm{~kg} \mathrm{HB} / \mathrm{kg}$ barley grains (Table 2). This value is similar to that reported previously [4] [9]. However, Kruglyakov [10] reported a production up to $10 \mathrm{~kg}$ of fresh green fodder out of $1 \mathrm{~kg}$ of barley seeds. The green fodder yield depends on type of grain and the growing conditions [9] [11]-[14].

The green fodder yield varies according to type of grain. It was reported by previous research that $1 \mathrm{~kg}$ of barley grains produced a green fodder yield ranging from 7 to $10 \mathrm{~kg}$ [9]-[14] indicating that barley and wheat were the most appropriate.

The chemical composition of HB is shown in Table 2. The germination of barley in this study resulted in about 18\% loss in DM. Shtaya [9] showed that the germination of wheat for 5 to 7 days resulted in a $17 \%$ loss of total DM while a $25 \%$ loss in DM of wheat after 12 days of sprouting. Peer and Leeson [15] (1985) and Chung et al. [16] (1989) reported dry matter (DM) losses ranging from $9.4 \%-18 \%$ with sprouting cereals from 5 to 7 days.

Fiber content, for example, increased from $3.5 \%$ in cereal barley grains to $6.5 \%$ and $8 \%$ in a 5 and $8 \mathrm{~d}$ green barley fodder, respectively.Fiber content, for example, was reported to be increased from $3.75 \%$ in cereal barley grains to $6 \%$ in a 5-d green barley fodder [16]. The nutrient composition of green fodder was changed by the growing cycle [17].

This study showed that the increase in CP content from d- 1 to d- 8 was almost $40 \%$ in HB when barley was sprouted (Table 3). Morgan et al. [18] (1992) and Peer and Lesson (1985) reported that protein content of green fodder is similar to barley grain, where the crude protein was higher in the green barley because of the relative decrease of other components.

Morgan et al. [18] found that the ash and protein content of sprouts increased from day 4 corresponding with the extension of the root, which allows mineral uptake. The absorption of nitrates facilitates the metabolism of nitrogenous compounds from carbohydrate reserves, thus increasing crude protein levels.

Table 2. Chemical composition of HB (DM basis).

\begin{tabular}{cc}
\hline Nutrient & HB \\
\hline Dry matter & 18.3 \\
Crude protein & 19.8 \\
Crude fiber & 10.4 \\
NDF & 35.4 \\
ADF & 11.9 \\
Ash & 3.6 \\
Calcium & 3.2 \\
Phosphorus & 4.1 \\
\hline
\end{tabular}

Table 3. Changes in nutrients contents during the germination process (\%DM).

\begin{tabular}{ccccc}
\hline & Day 0 & Day 3 & Day 6 & Day 8 \\
\hline Crude protein & 12.0 & 13.0 & 15.9 & 19.8 \\
Crude fiber & 3.5 & 4.9 & 6.5 & 8.0 \\
NDF & 13 & 19.0 & 28.0 & 35.0 \\
ADF & 6.0 & 7.8 & 8.9 & 11.0 \\
Ash & 2.2 & 2.9 & 3.0 & 3.6 \\
\hline
\end{tabular}




\subsection{Cost per kg HB}

The calculated production cost per $1 \mathrm{~kg}$ HB is 0.21 NIS. The main inputs were considered in calculation of HB cost (Table 4). Compared to the traditional roughage regularly fed to local sheep there is a saving of about 0.79 NIS/kg. The cost per ton of rations used in the feeding trial was 1510 and 1064 NIS for the control and HB rations, respectively.

\subsection{Performance Trial}

There are some arguments about the use of the sprouting grains for convenience of green forage production in hydroponics system to be as part of feed in livestock feeding systems [9] [19] [20]. Sole feeding of green fodder did not support the expected production traits in the animals whereas feeding in conjunction with dry fodder improved its utilization [19].

However, results were not consistent. These authors noted that the dry matter (DM) intake of green fodder by feedlot cattle and dairy cattle were low due to its high moisture content. However, Tudor et al. [20] reported an improvement in the performance of steers when given restricted hay diet plus $15.4 \mathrm{~kg}$ fresh hydroponics green fodder (about $1.8 \mathrm{~kg}$ added DM). It can be concluded that the biological and economical viabilities of production of green fodder will depend on sprouting systems, type and quality of the grain, particularly the germination rate, culturing conditions, management, and the local conditions [21].

Several researches have been conducted to determine the feeding value of green fodder [9] [11] [15] [22].

\subsection{Feed Intake}

The feed intake was similar by ewes under the feeding treatments (Table 4). However, the observed intake in this experiment was similar to what was reported from previous research [9] where ewes fed similar level of HB.

There are several factors described as influencing feed intake as milk production level, condition, temperature, shearing, type and quality of forage, pasturing system, breed, concentrate ration.

\subsection{Ewes Body Weight Change}

Ewes' average live weights under different feeding groups were increased during the entire feeding trial. Body weight of ewes fed the regular lactation diet gained similar to ewes fed the different forms of HB (Table 4).

The HB had no effect on ewes' average weight. Although level of CP in the HB ration was lower than the level recommended by NRC, ewes' performance was positive. This might be due to the effects of increased nutrients and the low antinutritional factors in HB. Tudor et al. [20] (2003) reported that most of the trials on livestock performance from hydroponic sprouts show no advantage to including them in the diet, especially when it replaces highly nutritious feeds such as grain. Cuddeford [17] describes some possible advantages of hydroponic sprouts for horses. Morgan et al. [18] found that pigs fed 4-day-old sprouts gained significantly less weight than those fed barley grain.

\subsection{Milk Yield and Milk Chemical Composition}

Milk yields and milk composition are presented in Table 5. Milk yield was not affected by HB. Milk protein,

\begin{tabular}{cccc} 
Table 4. The economical results of the experiment. & \\
\hline & Control & HB & Sig. \\
\hline Number of ewes & 24 & 24 & - \\
Weight change (kg) & $6 \pm 0.2$ & $5 \pm 0.8$ & $\mathrm{~ns}$ \\
Average daily gain (g) & $86 \pm 8.8$ & $77 \pm 5.9$ & $\mathrm{~ns}$ \\
Daily feed intake (kg) & $4.7 \pm 0.09$ & $4.4 \pm 0.1$ & $\mathrm{~ns}$ \\
Cost of 1 kg, feed NIS & $1.61^{\mathrm{a}} \pm 0.06$ & $1.06^{\mathrm{b}} \pm 0.09$ & $\mathrm{Sig}$ \\
Cost/ton, NIS & $1610^{\mathrm{a}} \pm 20.2$ & $1060^{\mathrm{b}} \pm 17.9$ & $\mathrm{Sig}$ \\
\hline
\end{tabular}

Rows of different superscripts differ significantly at $\mathrm{P}<0.05$. 
Table 5. Composition of milk from Awassi ewes fed HB.

\begin{tabular}{ccc}
\hline & Control & HB \\
\hline Milk yield, g/d & $1102 \pm 20$ & $1090 \pm 18$ \\
Protein before & $4.0 \pm 0.3$ & $4.2 \pm 0.2$ \\
Protein after & $4.9 \pm 0.3$ & $5.5 \pm 0.4$ \\
\% change & $1.4 \pm 0.3$ & $1.3 \pm 0.1$ \\
Fat before & $5.1 \pm 0.5$ & $5.0 \pm 0.2$ \\
Fat after & $5.8 \pm 0.6$ & $6.1 \pm 0.3$ \\
\% change & $1.0 \pm 0.05$ & $1.1 \pm 0.06$ \\
TS before & $16.0 \pm 2.2$ & $16.0 \pm 2.6$ \\
TS after & $15.8 \pm 1.0$ & $16.2 \pm 0.09$ \\
\% change & $0.2 \pm 0.01$ & $0.2 \pm 0.02$ \\
\hline
\end{tabular}

milk fat and total solids (TS) were also not affected by feeding HB (Table 5). Slight improvement in these parameters was observed in all treatment but was not significant. The relatively low averages of milk yield recorded can be explained by that the experiment was started one month after initiation of lactation and the general fair conditions of ewes used in the experiment. Milk yield observed in this study was lower compared with other findings reported by previous research when ewes fed HB [9]. Grigor'ev et al. [23] showed that replacing 50\% of the maize silage with $18 \mathrm{~kg}$ of hydroponic barley grass increased cows'milk yields by $8.7 \%$ although milk fat was depressed.

\subsection{Conception Rate, Abortion and Health Status}

The rate of conception was the same in ewes in different feeding treatments.

No cases of abortion were observed in the experimental ewes. Adequate levels of vitamin A (carotene) might be the explanation of maintaining pregnancy while consuming this type of diet. No signs of disease or health problem were observed during the feeding trial. The survival rate in experimental ewes was $100 \%$.

\section{Conclusion}

HB can replace regular roughage in lactating rations as part of total mixed rations. No negative effects on ewe's body conditions and productivity were observed. However, significant reduction in feed cost can be achieved when feeding rations incorporated with HB.

\section{References}

[1] Abu Omar, J., Daya, R. and Salama, A. (2012) Effects of Different Types of Olive Cake on the Performance and Carcass Quality of Awassi Lambs. Animal Feed Science and Technology, 171, 167-172. http://dx.doi.org/10.1016/j.anifeedsci.2011.11.002

[2] Sneath, R. and McIntosh, F. (2003) Review of Hydroponic Fodder Production for Beef Cattle. Department of Primary Industries: Queensland Australia 84. McKeehen, p. 54.

[3] Rodriguez-Muela, C., Rodriguez, H.E., Ruiz, O., Flores, A., Grado, J.A. and Arzola, C. (2004) Use of Green Fodder Produced in Hydroponic System as Supplement for Lactating Cows during the Dry Season. Proceedings of the American Society of Animal Science, 56, 271-274.

[4] Al-Karaki, G.N. (2011) Utilization of Treated Wastewater for Green Forage Production in a Hydroponic System. Emirates Journal of Food and Agriculture, 23, 80-94.

[5] Palestinian Central Bureau of Statistics (PCPS) (2010) The Annual Bulletin.

[6] NRC (1984) Nutrient Requirements of Beef Cattle. National Academic Press, Washington DC.

[7] AOAC (1990) Official Methods of Analysis. Association of Official Analytical Chemists, Inc., Arlington. 
[8] SAS (2000) SAS User's Guide: Statistics. 5th Edition, SAS Inst., Inc., Cary.

[9] Shtaya, I. (2004) Performance of Awassi Ewes Fed Barley Green Fodder. Master Thesis, An-Najah National University, Nablus.

[10] Kruglyakov, Yu.A. (1989) Construction of Equipment for Growing Green Fodder by a Hydroponic Technique. Traktory-I Sel'skokhozyaistvennye Mashiny, 6, 24-27.

[11] Fazaeli, H., Golmohammadi, H.A., Tabatabayee, S.N. and Asghari-Tabrizi, M. (2012) Productivity and Nutritive Value of Barley Green Fodder Yield in Hydroponic System. World Applied Sciences Journal, 16, 531-539.

[12] Al-Ajmi, A., Salih, A., Kadhim, I. and Othman, Y. (2009) Yield and Water Use Efficiency of Barley Fodder Produced under Hydroponic System in GCC Countries Using Tertiary Treated Sewage Effluents. Journal of Phytology, 5, 342348.

[13] Mukhopad, Y. (1994) Cultivating Green Forage and Vegetables in the Buryat Republic. Mezhdunarodnyi Sel'skokhozyaistvennyi Zhurnal, 6, 51-52.

[14] Buston, C.D.E., Gonzalez, E.L., Aguilera, B.A. and Esptnoz, G.J.A. (2002) Forrajehidropónicounaalternativa para la suplementacióncaprinaen el semidesier to Queretano pp: 383. XXXVIII Reunión Nacional de Investigación Pecuaria. Puebla, México.

[15] Peer, D.J. and Leeson, S. (1985) Feeding Value of Hydroponically Sprouted Barley for Poultry and Pigs. Animal Feed Science and Technology, 13, 183-190. http://dx.doi.org/10.1016/0377-8401(85)90021-5

[16] Chung, T.Y., Nwokolo, E.N. and Sim, J.S. (1989) Compositional and Digestibility Changes in Sprouted Barley and Canola Seeds. Plant Foods for Human Nutrition, 39, 267-278. http://dx.doi.org/10.1007/BF01091937

[17] Cuddeford, D. (1989) Hydroponic Grass. In Practice, 11, 211-214. http://dx.doi.org/10.1136/inpract.11.5.211

[18] Morgan, J., Hunter, R.R. and O’Haire, R. (1992) Limiting Factors in Hydroponic Barley Grass Production. Proceedings of the 8th International Congress on Soilless Culture, Hunter's Rest, 2-9 October 1992, 241-261.

[19] Prasad, R., Seghal, J.P., Patnayak, B.C. and Beniwal, R.K. (1998) Utilization of Artificially Grown Barley Fodder by Sheep. Indian Journal of Small Ruminants, 4, 63-68.

[20] Tudor, G., Darcy, T., Smith, P. and Shallcross, F. (2003) The Intake and Live Weight Change of Drought Master Steers Fed Hydroponically Grown, Young Sprouted Barley Fodder (Autograss). Department of Agriculture Western Australia.

[21] Fazaeli1, H., Golmohammadi, H.A., Shoayee, A.A., Montajebi, N. and Mosharraf, S. (2011) Performance of Feedlot Calves Fed Hydroponics Fodder Barley. Journal of Agricultural Science and Technology, 13, 367-375.

[22] Thomas, J.W. and Reddy, B.S. (1962) Sprouted Oats as a Feed for Dairy Cows. Quarterly Bulletin of the Michigan Agricultural Experiment Station, 44, 654-655.

[23] Grigor'ev, N.G., Fitsev, A.I. and Lesnitskaya, T.I. (1986) Nutritive Value of Hydroponic Feed and Its Use for Feeding High-Yielding Cows. Sel'skokhozyaistvennaya Biologiya, 7, 47-50. 